Article

\title{
Chlorophyll Fluorescence Imaging Analysis for Elucidating the Mechanism of Photosystem II Acclimation to Cadmium Exposure in the Hyperaccumulating Plant Noccaea caerulescens
}

\author{
Gülriz Bayçu ${ }^{1}$, Julietta Moustaka ${ }^{2}$ (), Nurbir Gevrek ${ }^{1}$ and Michael Moustakas ${ }^{1,3, *(1)}$ \\ 1 Division of Botany, Department of Biology, Faculty of Science, Istanbul University, 34134 Istanbul, Turkey; \\ gulrizb@istanbul.edu.tr (G.B.); ngevrek@gmail.com (N.G.) \\ 2 Department of Plant and Environmental Sciences, University of Copenhagen, Thorvaldsensvej 40, \\ DK-1871 Frederiksberg C, Denmark; moustaka@plen.ku.dk \\ 3 Department of Botany, Aristotle University of Thessaloniki, 54124 Thessaloniki, Greece \\ * Correspondence: moustak@bio.auth.gr; Tel.: +30-2310-99-8335
}

Received: 11 November 2018; Accepted: 13 December 2018; Published: 18 December 2018

\begin{abstract}
We provide new data on the mechanism of Noccaea caerulescens acclimation to Cd exposure by elucidating the process of photosystem II (PSII) acclimation by chlorophyll fluorescence imaging analysis. Seeds from the metallophyte $N$. caerulescens were grown in hydroponic culture for 12 weeks before exposure to 40 and $120 \mu \mathrm{M} \mathrm{Cd}$ for 3 and 4 days. At the beginning of exposure to $40 \mu \mathrm{M}$ $\mathrm{Cd}$, we observed a spatial leaf heterogeneity of decreased PSII photochemistry, that later recovered completely. This acclimation was achieved possibly through the reduced plastoquinone (PQ) pool signaling. Exposure to $120 \mu \mathrm{M} \mathrm{Cd}$ under the growth light did not affect PSII photochemistry, while under high light due to a photoprotective mechanism (regulated heat dissipation for protection) that down-regulated PSII quantum yield, the quantum yield of non-regulated energy loss in PSII $\left(\Phi_{N O}\right)$ decreased even more than control values. Thus, $N$. caerulescens plants exposed to $120 \mu \mathrm{M}$ $\mathrm{Cd}$ for 4 days exhibited lower reactive oxygen species (ROS) production as singlet oxygen $\left({ }^{1} \mathrm{O}_{2}\right)$. The response of $N$. caerulescens to Cd exposure fits the 'Threshold for Tolerance Model', with a lag time of $4 \mathrm{~d}$ and a threshold concentration of $40 \mu \mathrm{M} \mathrm{Cd}$ required for the induction of the acclimation mechanism.
\end{abstract}

Keywords: Cd toxicity; detoxification mechanism; photochemical quenching; photosynthetic heterogeneity; photoprotective mechanism; phytoremediation; plastoquinone pool; redox state; spatiotemporal variation

\section{Introduction}

Cadmium is a non-essential heavy metal that can occur in the environment in high concentrations as a consequence of numerous human activities, thus becoming toxic to all organisms [1-5]. Plants have developed several exclusive and effective mechanisms for $\mathrm{Cd}$ detoxification and tolerance, including control of $\mathrm{Cd}$ influx and acceleration of $\mathrm{Cd}$ efflux, $\mathrm{Cd}$ chelation and sequestration, $\mathrm{Cd}$ remobilization, and scavenging of $\mathrm{Cd}$-induced reactive oxygen species [5-10].

Hyperaccumulators are plant species that vigorously take up heavy metals, translocate them into the above-ground parts and isolate them into a risk-free state $[4,11]$. These plants can accumulate several percent of heavy metals in their dry mass [4]. Hyperaccumulators also have to stock the absorbed heavy metal in a manner that is not detrimental to vital enzymes and especially photosynthesis [12,13]. Hyperaccumulators can be used for phytoremediation and also for 
phytomining [4,14-16]. Phytoremediation is a cost-effective and environmentally-friendly technology that uses plants to remove the toxic metals from soils; it has been widely used in practice [14,17].

Noccaea caerulescens is known as a zinc-cadmium-nickel hyperaccumulator because it can accumulate these metals at extremely high concentrations in its aboveground tissues [18], and has been proposed as an ideal species for examining metal tolerance and hyperaccumulation [19]. It has recently gained a lot of attention due to its potential use in phytoremediation and phytomining [20,21]. Certain ecotypes of $N$. caerulescens can store as much as $14,000 \mu \mathrm{g} \mathrm{Cd} \mathrm{g}{ }^{-1}$ dry biomass without showing toxicity signs [22-24]. Cadmium concentrations in the leaves above $0.01 \%$ dry biomass are considered extraordinary and are the limit level for Cd hyperaccumulation [24,25].

Photosynthesis has been shown to be very sensitive to $C d$ either directly or indirectly $[4,26-31]$. A Cd-induced decrease in photosynthetic efficiency may result from disturbances in the electron transport [32,33], enzymatic activities involved in $\mathrm{CO}_{2}$ fixation [34,35], or from stomatal closure [36,37]. Photosystem II (PSII) is extremely sensitive to Cd that exerts multiple effects on both donor (it inhibits oxygen evolution) and acceptor sites (it inhibits electron transfer from quinone A, QA to quinone B, QB) $[28,33,38,39]$. The less susceptible component of the photosynthetic apparatus to $C d$ is thought to be PSI $[28,40]$.

We investigated photosynthetic acclimation to Cd toxicity using the hyperaccumulator Noccaea caerulescens. Our previous study indicated that despite the substantial high toxicity levels of $\mathrm{Zn}$ and $\mathrm{Cd}$ in N. caerulescens aboveground tissues, the photochemical energy use at PSII did not differ compared to controls [13]. However, the underlying mechanism of photosynthetic acclimation has not been elucidated. In the present study, in order to investigate the mechanism of N. caerulescens acclimation to $\mathrm{Cd}$ exposure and to clarify the process of photosynthetic acclimation, we treated in hydroponic culture N. caerulescens plants with 40 and $120 \mu \mathrm{M} \mathrm{Cd}$ for 3 and 4 days.

\section{Materials and Methods}

\subsection{Seed Collection and Experimental Design}

Seeds of Noccaea caerulescens F.K. Mey collected from a former Copper Mine area at Røros (Norway) were cultivated hydroponically in an environmental growth chamber as described previously [13].

After growth for 12 weeks, some plants were exposed to 40 or $120 \mu \mathrm{M} \mathrm{Cd}$ (supplied as $3 \mathrm{CdSO}_{4} .8 \mathrm{H}_{2} \mathrm{O}$ ) for 3 and 4 days while others were left to control growth conditions.

\subsection{Chlorophyll Fluorescence Imaging Analysis}

Chlorophyll fluorescence measurements were carried out with an Imaging-PAM Chlorophyll Fluorometer (Walz, Effeltrich, Germany) in dark-adapted leaves (15 min) of N. caerulescens plants, grown at 0 (control), 40 or $120 \mu \mathrm{M} \mathrm{Cd}$ for 3 and 4 days, as described previously [13,41]. Five leaves were measured from five different plants with eight areas of interest in each leaf. Two light intensities were selected for chlorophyll fluorescence measurements, a low light intensity that was similar to the growth light (300 $\mu \mathrm{mol}$ photons $\left.\mathrm{m}^{-2} \mathrm{~s}^{-1}, \mathrm{GL}\right)$ and a high light intensity $\left(1000 \mu \mathrm{mol}\right.$ photons $\mathrm{m}^{-2} \mathrm{~s}^{-1}, \mathrm{HL}$, more than three times that of the growth light). The measured and calculated chlorophyll fluorescence parameters with their definitions are given in Table 1.

Representative results of the measured chlorophyll fluorescence parameters are also displayed as color-coded images.

\subsection{Statistical Analyses}

All measurements that are expressed as mean \pm SD were analyzed by student $t$-test $(p<0.05)$. Five leaves from five different plants were analyzed in each treatment. In all graphs, the error bars are standard deviations, while columns with the same letter are not statistically different at $p<0.05$. 
Table 1. Definitions of all measured and calculated chlorophyll fluorescence parameters.

\begin{tabular}{|c|c|c|}
\hline $\begin{array}{l}\text { Chlorophyll Fluo-Rescence } \\
\text { Parameter }\end{array}$ & Definition & Calculation \\
\hline$F_{\mathrm{o}}$ & $\begin{array}{l}\text { Minimum chlorophyll } a \text { fluorescence in the } \\
\text { dark-adapted leaf (PSII centers open) }\end{array}$ & $\begin{array}{l}\text { Obtained by applying measuring photon } \\
\text { irradiance of } 1.2 \mu \mathrm{mol} \text { photons } \mathrm{m}^{-2} \mathrm{~s}^{-1}\end{array}$ \\
\hline$F_{\mathrm{m}}$ & $\begin{array}{l}\text { Maximum chlorophyll } a \text { fluorescence in the } \\
\text { dark-adapted leaf (PSII centers closed) }\end{array}$ & $\begin{array}{l}\text { Obtained with a saturating pulse (SP) of } \\
6000 \mu \mathrm{mol} \text { photons } \mathrm{m}^{-2} \mathrm{~s}^{-1}\end{array}$ \\
\hline$F_{\mathrm{s}}$ & Steady-state photosynthesis & $\begin{array}{l}\text { Measured after } 5 \mathrm{~min} \text { illumination time before } \\
\text { switching off the actinic light (AL) of } 300 \mu \mathrm{mol} \\
\text { photons } \mathrm{m}^{-2} \mathrm{~s}^{-1} \text { or } 1000 \mu \mathrm{mol} \text { photons } \mathrm{m}^{-2} \mathrm{~s}^{-1}\end{array}$ \\
\hline$F_{\mathrm{o}}{ }^{\prime}$ & $\begin{array}{l}\text { Minimum chlorophyll } a \text { fluorescence in the } \\
\text { light-adapted leaf }\end{array}$ & $\begin{array}{l}\text { It was computed by the Imaging Win software } \\
\text { (Heinz Walz GmbH, Effeltrich, Germany) as Fo }{ }^{\prime}= \\
\text { Fo/(Fv/Fm }+ \text { Fo/Fm') [42] }\end{array}$ \\
\hline$F_{\mathrm{m}}^{\prime}$ & $\begin{array}{l}\text { Maximum chlorophyll } a \text { fluorescence in the } \\
\text { light-adapted leaf }\end{array}$ & $\begin{array}{l}\text { Measured with saturating pulses (SPs) every } 20 \mathrm{~s} \\
\text { for } 5 \mathrm{~min} \text { after application of the actinic light (AL) } \\
\text { of } 300 \mu \mathrm{mol} \text { photons } \mathrm{m}^{-2} \mathrm{~s}^{-1} \text { or } 1000 \mu \mathrm{mol} \\
\text { photons } \mathrm{m}^{-2} \mathrm{~s}^{-1}\end{array}$ \\
\hline$F_{\mathrm{v}} / F_{\mathrm{m}}$ & $\begin{array}{l}\text { The maximum quantum efficiency of PSII } \\
\text { photochemistry }\end{array}$ & Calculated as $\left(F_{\mathrm{m}}-F_{\mathrm{o}}\right) / F_{\mathrm{m}}$ \\
\hline$\Phi_{\text {PSII }}$ & $\begin{array}{l}\text { The effective quantum yield of photochemical } \\
\text { energy conversion in PSII }\end{array}$ & Calculated as $\left(F_{\mathrm{m}}{ }^{\prime}-F_{\mathrm{s}}\right) / F_{\mathrm{m}}{ }^{\prime}$ \\
\hline$q_{\mathrm{P}}$ & The redox state of QA & Calculated as $\left(F_{\mathrm{m}}{ }^{\prime}-F_{\mathrm{s}}\right) /\left(F_{\mathrm{m}}{ }^{\prime}-F_{\mathrm{o}}{ }^{\prime}\right)$ \\
\hline NPQ & $\begin{array}{l}\text { The non-photochemical quenching that } \\
\text { reflects heat dissipation of excitation energy }\end{array}$ & Calculated as $\left(F_{\mathrm{m}}-F_{\mathrm{m}}{ }^{\prime}\right) / F_{\mathrm{m}}{ }^{\prime}$ \\
\hline ETR & The relative PSII electron transport rate & $\begin{array}{l}\text { Calculated as } \Phi_{P S I I} \times \text { Photosynthetic Photon Flux } \\
\text { Density } \times 0.5 \times 0.84\end{array}$ \\
\hline$\Phi_{N P Q}$ & $\begin{array}{l}\text { The quantum yield of regulated non- } \\
\text { photochemical energy loss in PSII, that is the } \\
\text { quantum yield for dissipation by down } \\
\text { regulation in PSII }\end{array}$ & Calculated as $F_{\mathrm{s}} / F_{\mathrm{m}}{ }^{\prime}-F_{\mathrm{s}} / F_{\mathrm{m}}$ \\
\hline$\Phi_{N O}$ & $\begin{array}{l}\text { The quantum yield of non-regulated energy } \\
\text { loss in PSII }\end{array}$ & Calculated as $F_{\mathrm{s}} / F_{\mathrm{m}}$ \\
\hline $1-q_{\mathrm{P}}$ & The fraction of closed PSII reaction centers & Calculated as $1-q_{\mathrm{P}}$ \\
\hline
\end{tabular}

\section{Results}

\subsection{Changes in the Maximum Quantum Efficiency of PSII Photochemistry after Cd Exposure}

At the beginning of exposure to $40 \mu \mathrm{M} \mathrm{Cd}$, the maximum quantum efficiency of PSII photochemistry $\left(F_{\mathrm{v}} / F_{\mathrm{m}}\right)$ in $N$. caerulescens decreased significantly but increased to control values at $120 \mu \mathrm{M} \mathrm{Cd}$ (Figure 1).

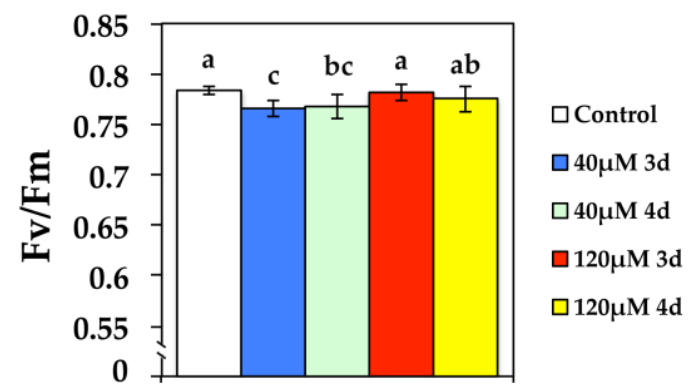

Figure 1. Changes in the maximum quantum efficiency of PSII $\left(F_{\mathrm{v}} / F_{\mathrm{m}}\right)$ in N. caerulescens plants grown at 0 (control), 40 or $120 \mu \mathrm{M} \mathrm{Cd}^{2+}$ for 3 and 4 days. 


\subsection{Changes in the Allocation of Absorbed Light Energy in PSII after Cd Exposure}

The quantum yield of photochemical energy conversion in PSII $\left(\Phi_{P S I I}\right)$, at both growth light (GL) and high light (HL) intensity decreased significantly compared to the control, after $3 \mathrm{~d}$ at $40 \mu \mathrm{M} \mathrm{Cd}$, while it improved during the $4 \mathrm{~d}$ (Figure 2). However, $\Phi_{P S I I}$ increased to control values after $3 \mathrm{~d}$ at $120 \mu \mathrm{M} \mathrm{Cd}$ at GL and stabilized to control values after 4 days of exposure (Figure 2a). High light (HL) exposure to $120 \mu \mathrm{M} \mathrm{Cd}$ resulted in decreased $\Phi_{P S I I}$ compared to controls (Figure 2b).

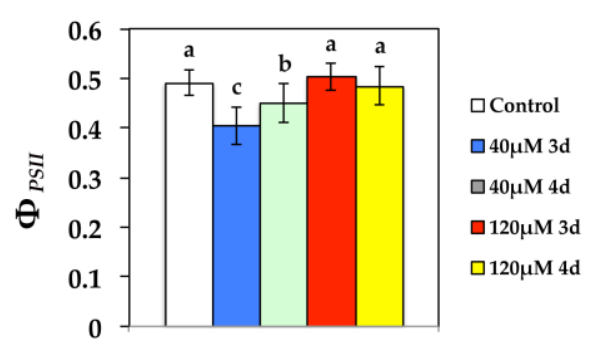

(a)

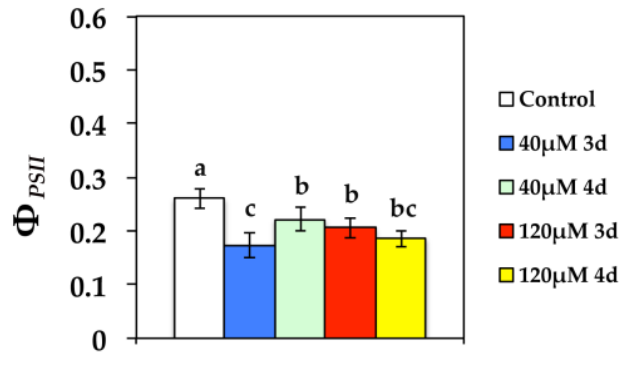

(b)

Figure 2. Changes in the quantum efficiency of PSII photochemistry $\left(\Phi_{P S I I}\right)$ in N. caerulescens measured (a) at $300 \mu \mathrm{mol}$ photons $\mathrm{m}^{-2} \mathrm{~s}^{-1}$ or (b) $1000 \mu \mathrm{mol}$ photons $\mathrm{m}^{-2} \mathrm{~s}^{-1}$. N. caerulescens plants were grown at 0 (control), 40 , or $120 \mu \mathrm{M} \mathrm{Cd}^{2+}$ for 3 and 4 days.

The quantum yield of regulated non-photochemical energy loss in PSII $\left(\Phi_{N P Q}\right)$ decreased significantly compared to the control after $3 \mathrm{~d}$ at $40 \mu \mathrm{M} \mathrm{Cd}$ at GL and increased to control values during the $4 \mathrm{~d}$ (Figure 3a). Exposure to $120 \mu \mathrm{M} \mathrm{Cd}$ resulted in decreased $\Phi_{N P Q}$ at GL compared to controls during the $4 \mathrm{~d}$ (Figure 3a). At $\mathrm{HL}, \Phi_{N P Q}$ remained unchanged at $40 \mu \mathrm{M} \mathrm{Cd}$, but increased significantly at $120 \mu \mathrm{M} \mathrm{Cd}$ (Figure $3 b$ ).

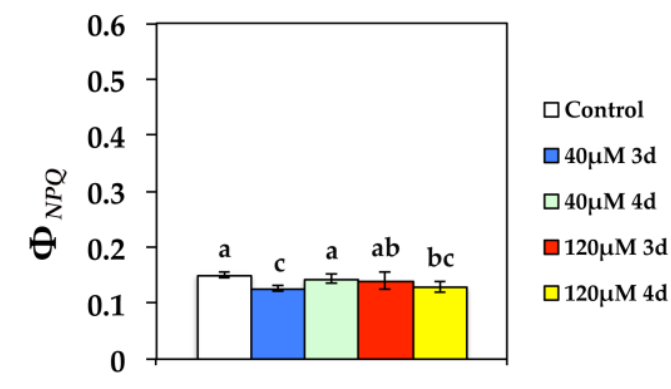

(a)

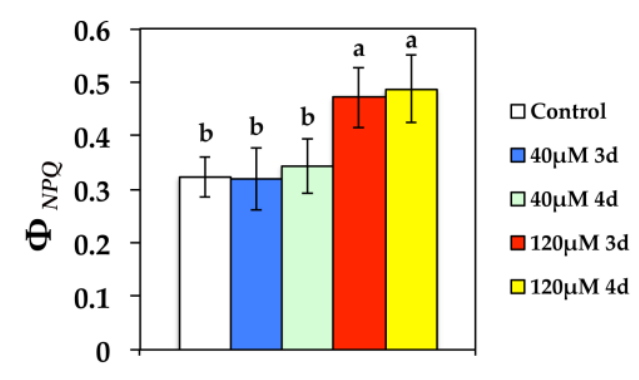

(b)

Figure 3. Changes in the quantum yield for dissipation by down regulation in PSII (regulated heat dissipation, a loss process serving for protection) $\left(\Phi_{N P Q}\right.$ ) measured at (a) $300 \mu \mathrm{mol}$ photons m $\mathrm{m}^{-2} \mathrm{~s}^{-1}$ or (b) $1000 \mu \mathrm{mol}$ photons $\mathrm{m}^{-2} \mathrm{~s}^{-1}$. N. caerulescens plants were grown at 0 (control), 40 , or $120 \mu \mathrm{M} \mathrm{Cd}^{2+}$ for 3 and 4 days.

The quantum yield of non-regulated energy loss in PSII $\left(\Phi_{N O}\right)$, a loss process due to PSII inactivity, at both GL and HL intensity, increased significantly compared to the control after $3 \mathrm{~d}$ exposure to $40 \mu \mathrm{M} \mathrm{Cd}$, while during the $4 \mathrm{~d}$ it decreased compared to $3 \mathrm{~d}$ (Figure 4). After exposure to $120 \mu \mathrm{M} \mathrm{Cd}$ for $3 \mathrm{~d}$ at GL, $\Phi_{N O}$ retained the same values compared to the controls, but increased during the $4 \mathrm{~d}$ (Figure 4a). However, $\Phi_{N O}$ decreased more than the control values at $120 \mu \mathrm{MCd}$ at HL (Figure 4b). 


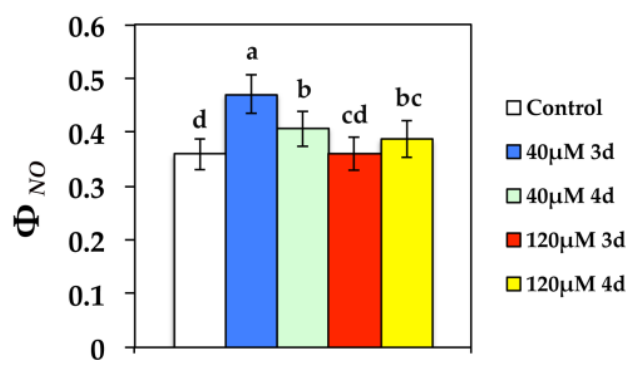

(a)

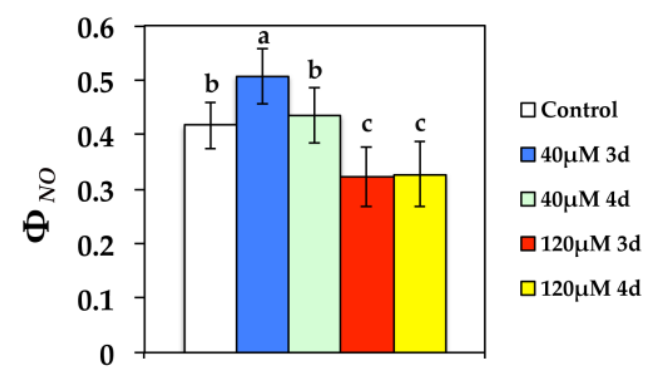

(b)

Figure 4. Changes in the quantum yield of non-regulated energy dissipated in PSII (non-regulated heat dissipation, a loss process due to PSII inactivity) $\left(\Phi_{N O}\right)$ measured at (a) $300 \mu \mathrm{mol}$ photons $\mathrm{m}^{-2} \mathrm{~s}^{-1}$ or (b) $1000 \mu \mathrm{mol}$ photons $\mathrm{m}^{-2} \mathrm{~s}^{-1}$. N. caerulescens plants were grown at 0 (control), 40 , or $120 \mu \mathrm{M} \mathrm{Cd}^{2+}$ for 3 and 4 days.

\subsection{Non-Photochemical Quenching and Electron Transport Rate in Response to Cd}

Non-photochemical quenching (NPQ) that reflects heat dissipation of excitation energy, decreased significantly compared to the control after $3 \mathrm{~d}$ at $40 \mu \mathrm{M} \mathrm{Cd}$ at GL, while it improved during the $4 \mathrm{~d}$ (Figure 5a). Exposure to $120 \mu \mathrm{M} \mathrm{Cd}$ resulted in decreased NPQ at GL compared to controls during the $4 \mathrm{~d}$ (Figure 5a). At HL, NPQ decreased significantly compared to the control after $3 \mathrm{~d}$ exposure to $40 \mu \mathrm{M} \mathrm{Cd}$, and increased to control values during the $4 \mathrm{~d}$, while after exposure to $120 \mu \mathrm{M} \mathrm{Cd}$ increased significantly compared to the controls (Figure 5b).

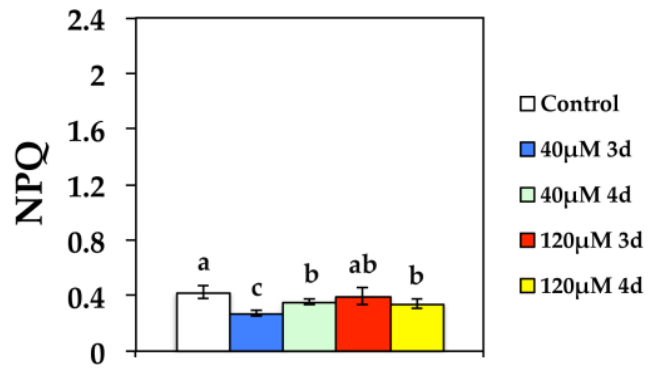

(a)

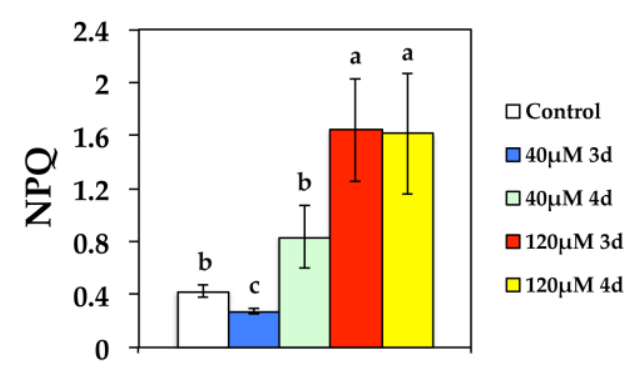

(b)

Figure 5. Changes in non-photochemical fluorescence quenching (NPQ) measured at (a) $300 \mu \mathrm{mol}$ photons $\mathrm{m}^{-2} \mathrm{~s}^{-1}$ or (b) $1000 \mu \mathrm{mol}$ photons $\mathrm{m}^{-2} \mathrm{~s}^{-1}$. N. caerulescens plants were grown at 0 (control), 40 or $120 \mu \mathrm{M} \mathrm{Cd}^{2+}$ for 3 and 4 days.

The electron transport rate (ETR), at both GL and HL intensity, decreased significantly compared to the control after $3 \mathrm{~d}$ at $40 \mu \mathrm{M} \mathrm{Cd}$, while it improved during the $4 \mathrm{~d}$ (Figure 6). However, ETR increased to control values after $3 \mathrm{~d}$ exposure to $120 \mu \mathrm{M} \mathrm{Cd}$ at GL and stabilized to control values after $4 \mathrm{~d}$ exposure (Figure 6a). High light exposure to $120 \mu \mathrm{M} \mathrm{Cd}$ resulted in decreased ETR compared to the controls (Figure 6b). 


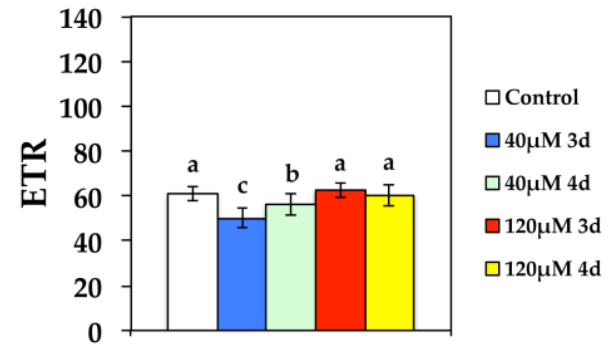

(a)

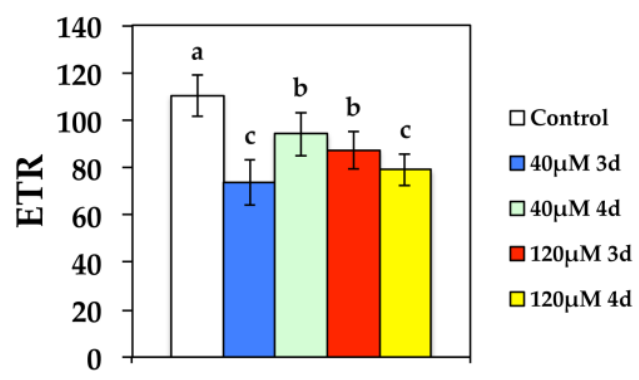

(b)

Figure 6. Changes in the relative PSII electron transport rate (ETR) measured at (a) $300 \mu \mathrm{mol}$ photons $\mathrm{m}^{-2} \mathrm{~s}^{-1}$ or (b) $1000 \mu \mathrm{mol}$ photons $\mathrm{m}^{-2} \mathrm{~s}^{-1}$. N. caerulescens plants were grown at 0 (control), 40 or $120 \mu \mathrm{M} \mathrm{Cd}^{2+}$ for 3 and 4 days.

\subsection{Changes in the Redox State of PSII after Cd Exposure}

The redox state of QA $\left(q_{\mathrm{P}}\right)$ that is a measure of the fraction of open PSII reaction centers, at both GL and HL intensity, decreased significantly compared to the control after $3 \mathrm{~d}$ at $40 \mu \mathrm{M} \mathrm{Cd}$, while it improved during the $4 \mathrm{~d}$ (Figure 7). However, $q_{\mathrm{P}}$ increased to control values after $3 \mathrm{~d}$ exposure to $120 \mu \mathrm{M} \mathrm{Cd}$ at GL and stabilized to control values after $4 \mathrm{~d}$ exposure (Figure 7a). High light exposure to $120 \mu \mathrm{M} \mathrm{Cd}$ resulted in a more reduced redox state of QA compared to controls, i.e., a lower fraction of open PSII reaction centers (Figure 7b).

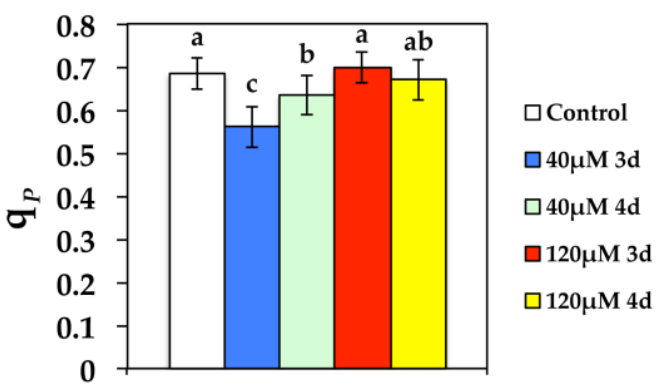

(a)

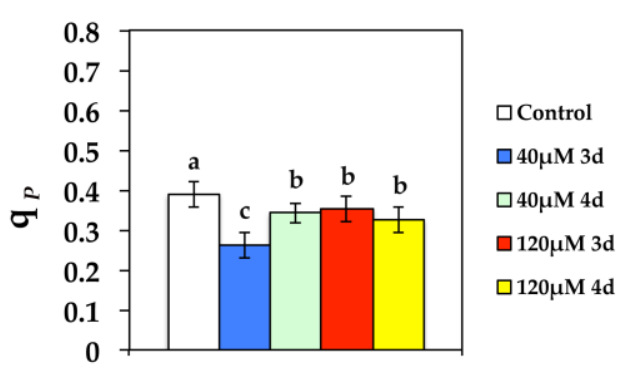

(b)

Figure 7. Changes in the photochemical fluorescence quenching, that is the relative reduction state of $\mathrm{Q}_{A}$, reflecting the fraction of open PSII reaction centers $\left(q_{\mathrm{P}}\right)$ measured at (a) $300 \mu \mathrm{mol}$ photons m $\mathrm{m}^{-2} \mathrm{~s}^{-1}$ or (b) $1000 \mu \mathrm{mol}$ photons $\mathrm{m}^{-2} \mathrm{~s}^{-1}$. N. caerulescens plants were grown at 0 (control), 40 , or $120 \mu \mathrm{M} \mathrm{Cd}^{2+}$ for 3 and 4 days.

\subsection{Spatiotemporal Variation of PSII Responses to Cd Exposure}

The major veins (mid-vein, first- and second-order veins) in N. caerulescens leaves grown under control growth conditions at both GL and HL defined areas with a lower fraction of open PSII reaction centers or a more reduced redox state of QA, while mesophyll cells expressed larger spatial heterogeneity with a larger fraction of open PSII reaction centers or a more oxidized redox state (Figures $8 \mathrm{e}$ and $9 \mathrm{~d}$ ).

The maximum quantum efficiency of PSII photochemistry $\left(F_{\mathrm{v}} / F_{\mathrm{m}}\right)$ show the smallest spatial heterogeneity even though it decreased significantly at $40 \mu \mathrm{M} \mathrm{Cd}$ and increased to control values at $120 \mu \mathrm{M} \mathrm{Cd}$ (Figure 8a). The quantum yield of photochemical energy conversion in PSII $\left(\Phi_{P S I I}\right)$ decreased significantly after $3 \mathrm{~d}$ at $40 \mu \mathrm{M} \mathrm{Cd}$ at GL, while it improved during the $4 \mathrm{~d}$, showing a high spatiotemporal leaf heterogeneity (Figure 8b). Among the chlorophyll fluorescence parameters with high spatiotemporal heterogeneity observed at GL, were the images of the quantum yield of non-regulated energy dissipated in PSII (non-regulated heat dissipation, a loss process due to 
PSII inactivity) $\left(\Phi_{N O}\right)$ (Figure 8d) and the images of the redox state of the PQ pool $\left(q_{\mathrm{P}}\right)$ (Figure 8e). The most severely affected leaf area after $3 \mathrm{~d}$ at $40 \mu \mathrm{M} \mathrm{Cd}$, was the left and right leaf side, while the central area was less affected (Figure $8 \mathrm{~d}, \mathrm{e}$ ). At the left and right leaf side after $3 \mathrm{~d}$ exposure to $40 \mu \mathrm{M} \mathrm{Cd}$, the quantum yield of non-regulated energy loss in PSII $\left(\Phi_{N O}\right)$ increased; thus, these areas exhibited increased singlet oxygen $\left({ }^{1} \mathrm{O}_{2}\right)$ production (Figure $8 \mathrm{~d}$ ), and also presented the lower $q_{\mathrm{P}}$ values (Figure 8e). However, in the left and right leaf side after $4 \mathrm{~d}$ exposure to $\mathrm{Cd}, \Phi_{N O}$ decreased (Figure $8 \mathrm{~d}$ ) and the redox state of the PQ pool increased $\left(q_{\mathrm{P}}\right)$ (Figure 8e). At exposure to $120 \mu \mathrm{M} \mathrm{Cd}$ at GL, leaf spatial heterogeneity decreased, and both $\Phi_{N O}$ (Figure $8 \mathrm{~d}$ ) and $q_{\mathrm{P}}$ (Figure 8e) stabilized to control values.

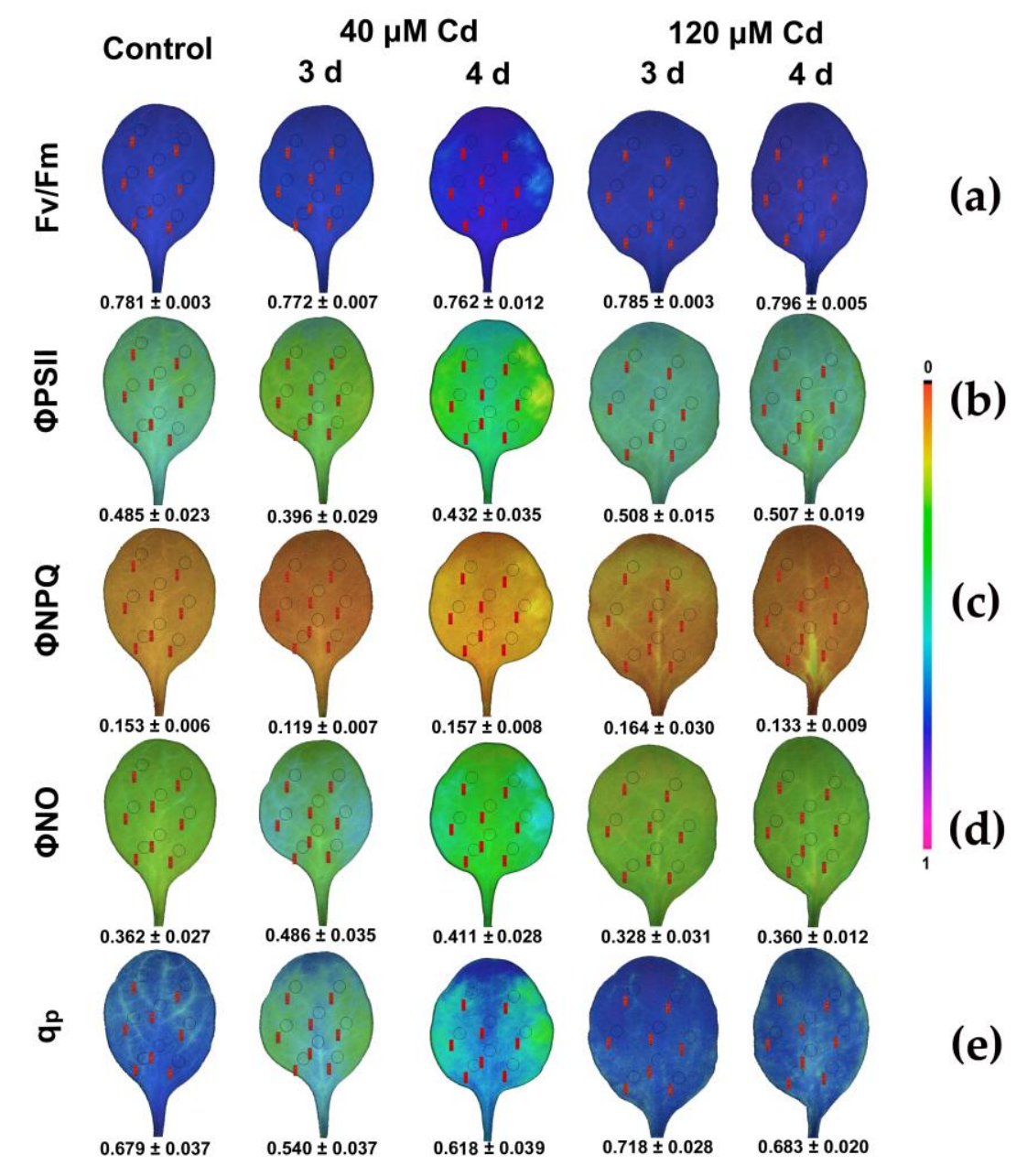

Figure 8. Representative chlorophyll fluorescence images of the maximum quantum efficiency $\left(F_{\mathrm{v}} / F_{\mathrm{m}}\right)$ of PSII after 15 min dark adaptation (a) and after 5 min illumination at $300 \mu \mathrm{mol}$ photons $\mathrm{m}^{-2} \mathrm{~s}^{-1}$ actinic light; of the actual (effective) quantum yield of PSII photochemistry $\left(\Phi_{P S I I}\right)(\mathbf{b})$, the quantum yield for dissipation by downregulation in PSII $\left(\Phi_{N P Q}\right)(\mathbf{c})$, the quantum yield of non-regulated energy loss in PSII $\left(\Phi_{N O}\right)(\mathbf{d})$, and the relative reduction state of $\mathrm{Q}_{A}$, reflecting the fraction of open PSII reaction centers $\left(q_{\mathrm{P}}\right)(\mathbf{e})$. N. caerulescens plants were grown at 0 (control), 40 or $120 \mu \mathrm{M} \mathrm{Cd}^{2+}$ for 3 and 4 days. The colour code depicted at the right side of the images ranges from black (pixel values 0.0 ) to purple (1.0). The eight areas of interest are shown in each image. The average value of each photosynthetic parameter of the leaf is presented in the figure.

Exposure of N. caerulescens to HL increased the spatiotemporal leaf heterogeneity (Figure 9) and the plants suffered more from Cd toxicity during the $3 \mathrm{~d}$ of exposure to $40 \mu \mathrm{M} \mathrm{Cd}$, but they recovered during the $4 \mathrm{~d}$. However, exposure to $120 \mu \mathrm{M} \mathrm{Cd}$ at HL revealed mild effects. This was realized by an 
increase in $\Phi_{N P Q}$ (Figure 9b) that down-regulated PSII quantum yield ( $\left.\Phi_{P S I I}\right)$ (Figure 9a) and decreased the quantum yield of non-regulated energy loss in PSII $\left(\Phi_{N O}\right)$ (Figure 9c).

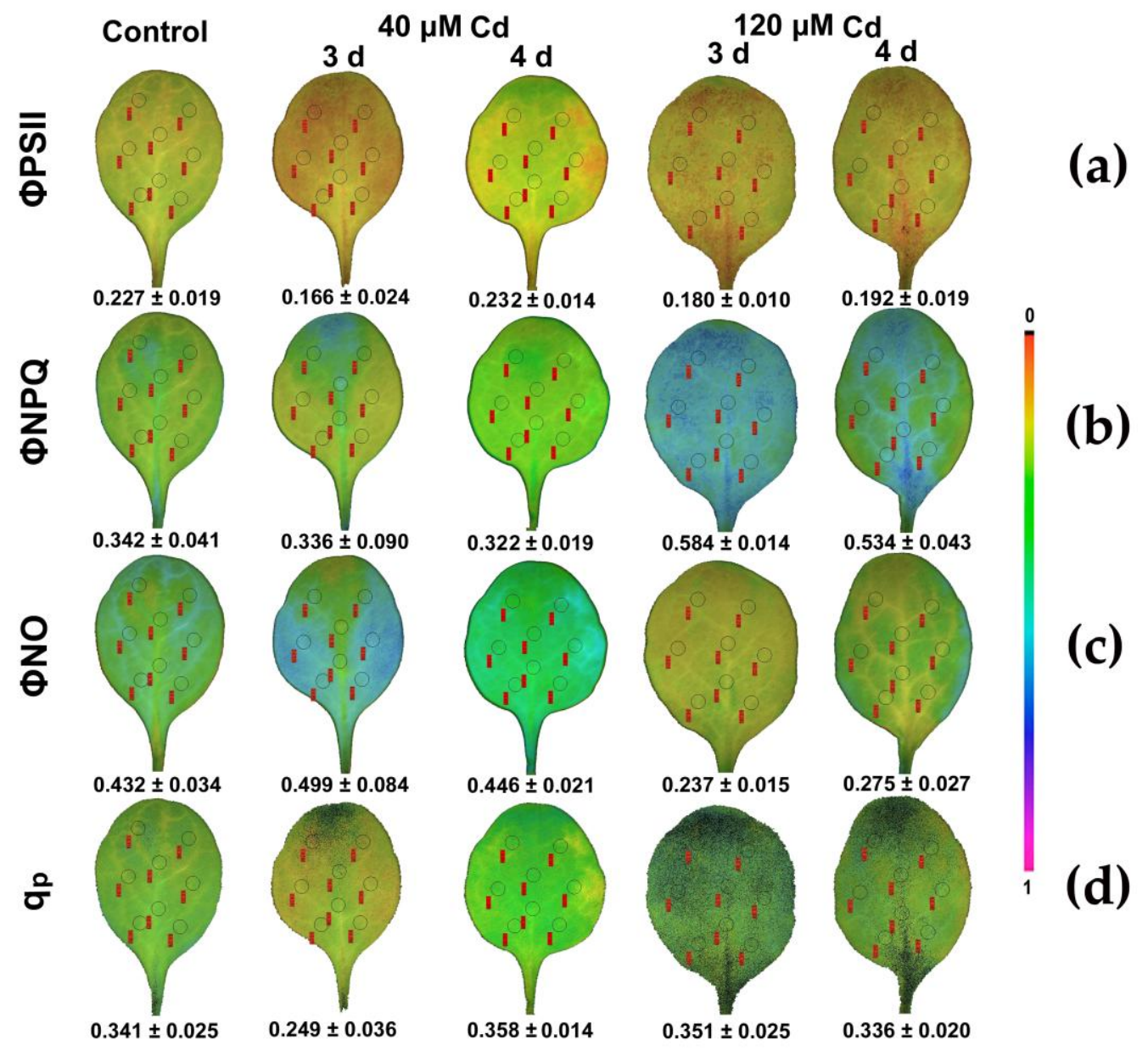

Figure 9. Representative chlorophyll fluorescence images after $5 \mathrm{~min}$ illumination at $1000 \mu \mathrm{mol}$ photons $\mathrm{m}^{-2} \mathrm{~s}^{-1}$ actinic light; of the actual (effective) quantum yield of PSII photochemistry $\left(\Phi_{P S I I}\right)$ (a), the quantum yield for dissipation by downregulation in PSII $\left(\Phi_{N P Q}\right)(\mathbf{b})$, the quantum yield of non-regulated energy loss in PSII $\left(\Phi_{N O}\right)(\mathbf{c})$, and the relative reduction state of $Q_{A}$, reflecting the fraction of open PSII reaction centers $\left(q_{\mathrm{P}}\right)(\mathrm{d}) N$. caerulescens plants were grown at 0 (control), 40 or $120 \mu \mathrm{M} \mathrm{Cd}^{2+}$ for 3 and 4 days. The colour code depicted at the right side of the images ranges from black (pixel values 0.0 ) to purple (1.0). The eight areas of interest are shown in each image. The average value of each photosynthetic parameter of the leaf is presented in the figure.

\section{Discussion}

The type of damage on PSII that has frequently been identified as the main target of $\mathrm{Cd}$ toxicity on photosynthesis strongly depends on light conditions [4,43-46]. At GL, the damage of the PSII function is mainly due to the impairment that results from the replacement by $\mathrm{Cd}^{2+}$ of the $\mathrm{Mg}^{2+}$ ion in the chlorophyll molecules of the light-harvesting complex II, while in HL it is mainly from direct damage to the PSII reaction center [4,44-46].

$N$. caerulescens leaves grown under control growth conditions at both GL and HL show a spatial heterogeneity in PSII functionality (Figures 8 and 9). This spatial heterogeneity may be attributed to 'patchy stomatal behavior', in which stomata in adjacent regions exhibit significantly different mean apertures from each other, resulting in significantly different stomatal conductance $\left(g_{s}\right)[47,48]$. Stomatal conductance decreases when the stomata close; this is used as an indicator of the extent of stomatal opening $[49,50]$. It is assumed that spatial variation in the quantum efficiency of PSII 
photochemistry $\left(\Phi_{P S I I}\right)$ arises from local differences in internal $\mathrm{CO}_{2}$ concentrations, which in turn result from changes in stomatal conductance due to patchy stomatal behavior [51]. A body of evidence suggests that patterns of $\Phi_{P S I I}$ can be used to calculate stomatal conductance [51-55].

At the beginning of exposure to $40 \mu \mathrm{M}, \mathrm{Cd} \Phi_{P S I I}$ decreased significantly at the left and right leaf sides (Figures $8 \mathrm{~b}$ and $9 \mathrm{a}$ ), with a simultaneous decrease in $\Phi_{N P Q}$ (Figures $8 \mathrm{c}$ and $9 \mathrm{~b}$ ) resulting in an increase of the quantum yield of non-regulated non-photochemical energy loss $\left(\Phi_{N O}\right)$ (Figures 8d and 9c). The increase in $\Phi_{N O}$ indicates that photochemical energy conversion and photoprotective regulatory mechanism were insufficient, pointing to serious problems of the plant to cope with the absorbed light energy $[56,57] . \Phi_{N O}$ consists of chlorophyll fluorescence internal conversions and intersystem crossing, which indicate the formation of singlet oxygen $\left({ }^{1} \mathrm{O}_{2}\right)$ via the triplet state of chlorophyll $\left({ }^{3} \mathrm{chl}{ }^{*}\right)[13,58,59]$. After $3 \mathrm{~d}$ exposure to $40 \mu \mathrm{MCd}, N$. caerulescens leaves exhibited increased ${ }^{1} \mathrm{O}_{2}$ production at the left and right leaf sides, since $\Phi_{N O}$ increased significantly at those areas. Thus, although $\mathrm{Cd}^{2+}$ is a redox-inert element, it produces reactive oxygen species [28]. The simultaneous reduced PQ pool that was observed mainly at the left and right leaf sides mediated stomatal closure probably through the generation of mesophyll chloroplastic hydrogen peroxide $\left(\mathrm{H}_{2} \mathrm{O}_{2}\right)$ [60]. The stomatal closure at these areas implies decreased transpiration rates that slow down $\mathrm{Cd}$ supply.

During the $4 \mathrm{~d}$ exposure to $40 \mu \mathrm{M} \mathrm{Cd}, \Phi_{P S I I}$ increased at the left and right leaf sides (Figures $8 b$ and $9 a$ ), with a simultaneous increase in $\Phi_{N P Q}$ (Figures $8 c$ and $9 b$ ) resulting in a decrease of $\Phi_{N O}$ (Figures $8 \mathrm{~d}$ and $9 \mathrm{c}$ ) compared to $3 \mathrm{~d}$ exposure. This response is attributed to both the possible $\mathrm{Cd}$ detoxification mechanism achieved by vacuolar sequestration, that seems to be the main mechanism for Cd detoxification [61-63], and to the reduced plastoquinone (PQ) pool that mediated stomatal closure and decreased Cd supply at the affected leaf area, leading to the acclimation of N. caerulescens to $\mathrm{Cd}$ exposure. Under exposure to $120 \mu \mathrm{M} \mathrm{Cd}$ at $\mathrm{HL}$, the quantum yield of non-regulated energy loss in PSII $\left(\Phi_{N O}\right)$ decreased even more than control values, and thus exhibited lower singlet oxygen $\left({ }^{1} \mathrm{O}_{2}\right)$ production. This was due to the photoprotective mechanism that can divert absorbed light to other processes such as thermal dissipation, preventing the photosynthetic apparatus from oxidative damage [64-70].

The observed spatial heterogeneity in the quantum yield of linear electron transport ( $\left.\Phi_{P S I I}\right)$ in $N$. caerulescens leaves exposed to $40 \mu \mathrm{M} \mathrm{Cd}$ for $3 \mathrm{~d}$ (Figures $8 \mathrm{~b}$ and $9 \mathrm{a}$ ) is in accordance to elemental imaging using laser ablation inductively-coupled plasma mass spectrometry, performed on whole leaves of the hyperaccumulator $N$. caerulescens that revealed differences in the supply of $\mathrm{Cd}$ over the whole leaf area, suggesting a heterogeneous distribution across the leaf [71]. Useful information can be obtained by combining chlorophyll fluorescence images, followed by laser ablation inductively-coupled plasma mass spectrometry on whole leaves of the hyperaccumulator N. caerulescens exposed to Cd.

It seems that spatiotemporal variations in the redox state of the PQ pool related to stomatal conductance, an indicator of the extent of stomatal opening [50], are interconnected to the heterogeneous distribution of $\mathrm{Cd}$ over the entire leaf area [71]. Thus, the spatial heterogeneity in the redox state of the PQ pool throughout the whole leaf area (Figures $8 \mathrm{e}$ and $9 \mathrm{~d}$ ) reveals a spatial supply of $\mathrm{Cd}$ across the leaf. Recently, $\mathrm{Cd}^{2+}$ root influx has been shown to exhibit spatiotemporal patterns [72]. A heterogeneous distribution of a reduced PQ pool gives rise to a spatial distribution of $\mathrm{H}_{2} \mathrm{O}_{2}$ accumulation [73]. Still, reactive oxygen species $\left(\mathrm{O}_{2}{ }^{-}, \mathrm{H}_{2} \mathrm{O}_{2}\right)$ production corresponds to spatial accumulation metal patterns [74].

In our work, the response of $N$. caerulescens to $\mathrm{Cd}$ exposure fits the 'Threshold for Tolerance Model', with a lag time or/and a threshold concentration required for the induction of a tolerance mechanism [75-78]. Concurrent to this model, mild stress or short exposure times can produce significant effects on plants, while moderate stress or longer exposure times have less or no effect [79]. In accordance with this model, $40 \mu \mathrm{M} \mathrm{Cd}$ and $3 \mathrm{~d}$ exposure time caused significant effects on PSII functioning, while $120 \mu \mathrm{M} \mathrm{Cd}$ or $4 \mathrm{~d}$ exposure time have less or no effect. A lag-time of $4 \mathrm{~d}$ exposure to $40 \mu \mathrm{M} \mathrm{Cd}$ was required for $N$. caerulescens to activate stress-coping mechanisms. 


\section{Conclusions}

Acclimation to $\mathrm{Cd}$ exposure was achieved through the possible $\mathrm{Cd}$ detoxification mechanism done by vacuolar sequestration and the reduced plastoquinone (PQ) pool signaling that mediated stomatal closure and decreased $\mathrm{Cd}$ supply at the affected leaf area. The response of $\mathrm{N}$. caerulescens to $\mathrm{Cd}$ exposure fits the 'Threshold for Tolerance Model', with a lag time of $4 \mathrm{~d}$ and a threshold concentration of $40 \mu \mathrm{M} \mathrm{Cd}$ required for the induction of the acclimation mechanism through the reduced PQ pool that mediated stomatal closure probably by the generation of mesophyll chloroplastic hydrogen peroxide $\left(\mathrm{H}_{2} \mathrm{O}_{2}\right)$ [60], which acts as a fast acclimation signaling molecule [73,80], as well as activates the $\mathrm{Cd}$ detoxification mechanism through vacuolar sequestration [61-63]. The mode of Cd damage on PSII strongly depends on the irradiance conditions [4,43-46]. Chlorophyll fluorescence imaging analysis is a non-invasive tool to assess the physiological status of plants and detect the impacts of environmental stress [81-83], permitting also the visualization of the spatiotemporal variations in PSII efficiency [76]. As it was shown in our experiments, it is also capable of elucidating the mechanism of photosystem II acclimation to Cd exposure.

Author Contributions: G.B. and M.M. conceived and designed the experiments and analyzed the data; J.M. and N.G. performed the experiments and analyzed the data; M.M. wrote the paper; All authors review and approved the manuscript.

Funding: This research was funded by the Istanbul University Scientific Research Projects Thesis-2015-44682 and BEK-2016-21903.

Conflicts of Interest: The authors declare no conflict of interest. The funders had no role in the design of the study; in the collection, analyses, or interpretation of data; in the writing of the manuscript, and in the decision to publish the results.

\section{References}

1. Lagerwerff, J.V.; Specht, A.W. Contamination of roadside soil and vegetation with cadmium, nickel, lead, and zinc. Environ. Sci. Technol. 1970, 4, 583-586. [CrossRef]

2. Buchauer, M.J. Contamination of soil and vegetation near a zinc smelter by zinc, cadmium, copper, and lead. Environ. Sci. Technol. 1973, 7, 131-135. [CrossRef]

3. McBride, M.B.; Richards, B.K.; Steenhuis, T.; Russo, J.J.; Sauvé, S. Mobility and solubility of toxic metals and nutrients in soil fifteen years after sewage sludge application. Soil Sci. 1997, 162, 487-500. [CrossRef]

4. Küpper, H.; Parameswaran, A.; Leitenmaier, B.; Trtílek, M.; Šerlík, I. Cadmium induced inhibition of photosynthesis and long-term acclimation to cadmium stress in the hyperaccumulator Thlaspi caerulescens. New Phytol. 2007, 175, 655-674. [CrossRef] [PubMed]

5. Yao, X.; Cai, Y.; Yu, D.; Liang, G. bHLH104 confers tolerance to cadmium stress in Arabidopsis thaliana. J. Integr. Plant Biol. 2018, 60, 691-702. [CrossRef] [PubMed]

6. Hall, J.L. Cellular mechanisms for heavy metal detoxification and tolerance. J. Exp. Bot. 2002, 53, 1-11. [CrossRef] [PubMed]

7. Kim, D.Y.; Bovet, L.; Maeshima, M.; Martinoia, E.; Lee, Y. The ABC transporter AtPDR8 is a cadmium extrusion pump conferring heavy metal resistance. Plant J. 2007, 50, 207-218. [CrossRef] [PubMed]

8. Dalcorso, G.; Farinati, S.; Furini, A. Regulatory networks of cadmium stress in plants. Plant Signal. Behav. 2010, 5, 663-667. [CrossRef] [PubMed]

9. Lin, Y.F.; Aarts, M.G. The molecular mechanism of zinc and cadmium stress response in plants. Cell Mol. Life Sci. 2012, 69, 3187-3206. [CrossRef] [PubMed]

10. Shi, Y.Z.; Zhu, X.F.; Wan, J.X.; Li, G.X.; Zheng, S.J. Glucose alleviates cadmium toxicity by increasing cadmium fixation in root cell wall and sequestration into vacuole in Arabidopsis. J. Integr. Plant Biol. 2015, 57, 830-837. [CrossRef] [PubMed]

11. Brooks, R.R.; Lee, J.; Reeves, R.D.; Jaffre, T. Detection of nickeliferous rocks by analysis of herbarium species of indicator plants. J. Geochem. Explor. 1977, 7, 49-57. [CrossRef]

12. Leitenmaier, B.; Küpper, H. Cadmium uptake and sequestration kinetics in individual leaf cell protoplasts of the Cd/Zn hyperaccumulator Thlaspi caerulescens. Plant Cell Environ. 2011, 34, 208-219. [CrossRef] [PubMed] 
13. Bayçu, G.; Gevrek-Kürüm, N.; Moustaka, J.; Csatári, I.; Rognes, S.E.; Moustakas, M. Cadmium-zinc accumulation and photosystem II responses of Noccaea caerulescens to Cd and Zn exposure. Environ. Sci. Pollut. Res. 2017, 24, 2840-2850. [CrossRef] [PubMed]

14. Baker, A.J.M.; McGrath, S.P.; Sidoli, C.M.D.; Reeves, R.D. The possibility of situ heavy metal decontamination of polluted soils using crops of metal-accumulating plants. Resour. Conserv. Recycl. 1994, 11, 41-49. [CrossRef]

15. McGrath, S.P.; Zhao, F.J. Phytoextraction of metals and metalloids from contaminated soils. Curr. Opin. Biotechnol. 2003, 14, 277-282. [CrossRef]

16. Chaney, R.L.; Angle, J.S.; McIntosh, M.S.; Reeves, R.D.; Li, Y.M.; Brewer, E.P.; Chen, K.Y.; Roseberg, R.J.; Perner, H.; Synkowski, E.C.; et al. Using hyperaccumulator plants to phytoextract Soil Ni and Cd. Z. Naturforsch. C 2005, 60, 190-198. [PubMed]

17. Zhang, X.D.; Wang, Y.; Li, H.B.; Yang, Z.M. Isolation and identification of rapeseed (Brassica napus) cultivars for potential higher and lower Cd accumulation. J. Plant Nutr. Soil Sci. 2018, 181, 479-487. [CrossRef]

18. Escarré, J.; Lefèbvre, C.; Gruber, W.; Leblanc, M.; Lepart, J.; Rivière, Y.; Delay, B. Zinc and cadmium hyperaccumulation by Thlaspi caerulescens from metalliferous and nonmetalliferous sites in the Mediterranean area: Implications for phytoextraction. New Phytol. 2000, 145, 429-437.

19. Assunção, A.G.L.; Bookum, W.M.; Nelissen, H.J.M.; Vooijs, R.; Schat, H.; Ernst, W.H.O. Differential metal-specific tolerance and accumulation patterns among Thlaspi caerulescens populations originating from different soil types. New Phytol. 2003, 159, 411-419. [CrossRef]

20. Escarré, J.; Lefèbvre, C.; Frérot, H.; Mahieu, S.; Noret, N. Metal concentration and metal mass of metallicolous, non metallicolous and serpentine Noccaea caerulescens populations, cultivated in different growth media. Plant Soil 2013, 370, 197-221. [CrossRef]

21. Mousset, M.; David, P.; Petit, C.; Pouzadoux, J.; Hatt, C.; Flaven, E.; Ronce, O.; Mignot, A. Lower selfing rates in metallicolous populations than in non-metallicolous populations of the pseudometallophyte Noccaea caerulescens (Brassicaceae) in Southern France. Ann. Bot. 2016, 117, 507-519. [CrossRef] [PubMed]

22. Lasat, M.M.; Pence, N.S.; Garvin, D.F.; Ebbs, S.D.; Kochian, L.V. Molecular physiology of zinc transport in the Zn hyperaccumulator Thlaspi caerulescens. J. Exp. Bot. 2000, 51, 71-79. [CrossRef] [PubMed]

23. Lombi, E.; Zhao, F.J.; Dunham, S.J.; McGrath, S.P. Cadmium accumulation in populations of Thlaspi caerulescens and Thlaspi goesingense. New Phytol. 2000, 145, 11-20. [CrossRef]

24. Assunção, A.G.L.; Schat, H.; Aarts, M.G.M. Thlaspi caerulescens, an attractive model species to study heavy metal hyperaccumulation in plants. New Phytol. 2003, 159, 351-360. [CrossRef]

25. Baker, A.J.M.; McGrath, S.P.; Reeves, D.R.; Smith, J.A.C. Metal hyperaccumulator plants: A review of the ecology and physiology of a biological resource for phytoremediation of metal-polluted soils. In Phytoremediation of Contaminated Soils and Water; Terry, N., Banuelos, G., Eds.; CRC Press: Boca Raton, FL, USA, 2000; pp. 171-188.

26. Greger, M.; Ögren, E. Direct and indirect effects of $\mathrm{Cd}^{2+}$ on photosynthesis in sugar beet (Beta vulgaris). Physiol. Plant. 1991, 83, 129-135. [CrossRef]

27. Ouzounidou, G.; Moustakas, M.; Eleftheriou, E.P. Physiological and ultrastructural effects of cadmium on wheat (Triticum aestivum L.) leaves. Arch. Environ. Contam. Toxicol. 1997, 32, 154-160. [CrossRef] [PubMed]

28. Ekmekçi, Y.; Tanyolaç, D.; Ayhan, B. Effects of cadmium on antioxidant enzyme and photosynthetic activities in leaves of two maize cultivars. J. Plant Physiol. 2008, 165, 600-611. [CrossRef] [PubMed]

29. Liu, C.; Guo, J.; Cui, Y.; Lü, T.; Zhang, X.; Shi, G. Effects of cadmium and salicylic acid on growth, spectral reflectance and photosynthesis of castor bean seedlings. Plant Soil 2011, 344, 131-141. [CrossRef]

30. Parmar, P.; Kumari, N.; Sharma, V. Structural and functional alterations in photosynthetic apparatus of plants under cadmium stress. Bot. Stud. 2013, 54, 45. [CrossRef] [PubMed]

31. Xue, Z.C.; Gao, H.Y.; Zhang, L.T. Effects of cadmium on growth, photosynthetic rate, and chlorophyll content in leaves of soybean seedlings. Biol. Plant. 2013, 57, 587-590. [CrossRef]

32. Baszynski, T.; Wajda, L.; Krol, M.; Wolinska, D.; Krupa, Z.; Tukendorf, A. Photosynthetic activities of cadmium-treated tomato plants. Physiol. Plant. 1980, 48, 365-370. [CrossRef]

33. Sigfridsson, K.G.V.; Bernát, G.; Mamedov, F.; Styring, S. Molecular interference of $\mathrm{Cd}^{2+}$ with Photosystem II. Biochim. Biophys. Acta 2004, 1659, 19-31. [CrossRef] [PubMed]

34. Malik, D.; Sheoran, I.S.; Singh, R. Carbon metabolism in leaves of cadmium treated wheat seedlings. Plant Physiol. Biochem. 1992, 30, 223-229. 
35. Krantev, A.; Yordanova, R.; Janda, T.; Szalai, G.; Popova, L. Treatment with salicylic acid decreases the effect of cadmium on photosynthesis in maize plants. J. Plant Physiol. 2008, 165, 920-931. [CrossRef] [PubMed]

36. Poschenrieder, C.; Gunse, B.; Barcelo, J. Influence of cadmium on water relations, stomatal resistance, and abscisic acid content in expanding bean leaves. Plant Physiol. 1989, 90, 1365-1371. [CrossRef] [PubMed]

37. Shi, G.R.; Cai, Q.S. Photosynthetic and anatomic responses of peanut leaves to cadmium stress. Photosynthetica 2008, 46, 627-630. [CrossRef]

38. Krupa, Z.; Moniak, M. The stage of leaf maturity implicates the response of the photosynthetic apparatus to cadmium toxicity. Plant Sci. 1998, 138, 149-156. [CrossRef]

39. Pagliano, C.; Raviolo, M.; Dalla Vecchia, F.; Gabbrielli, R.; Gonnelli, C.; Rascio, N.; Barbato, R.; La Rocca, N. Evidence for PSII-donor-side damage and photoinhibition induced by cadmium treatment on rice (Oryza sativa L.). J. Photochem. Photobiol. B Biol. 2006, 84, 70-78. [CrossRef] [PubMed]

40. Chugh, L.K.; Sawhney, S.K. Photosynthetic activities of Pisum sativum seedlings grown in presence of cadmium. Plant Physiol. Biochem. 1999, 37, 297-303. [CrossRef]

41. Moustaka, J.; Panteris, E.; Adamakis, I.D.S.; Tanou, G.; Giannakoula, A.; Eleftheriou, E.P.; Moustakas, M. High anthocyanin accumulation in poinsettia leaves is accompanied by thylakoid membrane unstacking, acting as a photoprotective mechanism, to prevent ROS formation. Environ. Exp. Bot. 2018, 154, 44-55. [CrossRef]

42. Oxborough, K.; Baker, N.R. Resolving chlorophyll a fluorescence images of photosynthetic efficiency into photochemical and non-photochemical components-calculation of qP and Fv-/Fm- without measuring Fo-. Photosynth. Res. 1997, 54, 135-142. [CrossRef]

43. Cedeno-Maldonado, A.; Swader, J.A.; Heath, R.L. The cupric ion as an inhibitor of photosynthetic electron transport in isolated chloroplasts. Plant Physiol. 1972, 50, 698-701. [CrossRef] [PubMed]

44. Küpper, H.; Küpper, F.; Spiller, M. Environmental relevance of heavy metal substituted chlorophylls using the example of water plants. J. Exp. Bot. 1996, 47, 259-266. [CrossRef]

45. Küpper, H.; Küpper, F.; Spiller, M. In situ detection of heavy metal substituted chlorophylls in water plants. Photosynth. Res. 1998, 58, 125-133. [CrossRef]

46. Küpper, H.; Setlík, I.; Spiller, M.; Küpper, F.C.; Prásil, O. Heavy metal-induced inhibition of photosynthesis: Targets of in vivo heavy metal chlorophyll formation. J. Phycol. 2002, 38, 429-441. [CrossRef]

47. Weyers, J.D.B.; Lawson, T. Heterogeneity in stomatal characteristics. Adv. Bot. Res. 1997, 26, 317-352.

48. Lawson, T.; Morison, J. Visualising patterns of $\mathrm{CO}_{2}$ diffusion in leaves. New Phytol. 2006, 169, 637-640. [CrossRef] [PubMed]

49. Omasa, K.; Hashimoto, Y.; Aiga, I. Observation of stomatal movements of intact plants using an image instrumentation system with a light microscope. Plant Cell Physiol. 1983, 24, 281-288. [CrossRef]

50. Jones, H.G. Use of thermography for quantitative studies of spatial and temporal variation of stomatal conductance over leaf surfaces. Plant Cell Environ. 1999, 22, 1043-1055. [CrossRef]

51. Lawson, T.; Weyers, J. Spatial and temporal variation in gas exchange over the lower surface of Phaseolus vulgaris L. primary leaves. J. Exp. Bot. 1999, 50, 1381-1391. [CrossRef]

52. Eckstein, J.; Beyschlag, W.; Mott, K.A.; Ryel, R.J. Changes in photon flux can induce stomatal patchiness. Plant Cell Environ. 1996, 12, 559-568. [CrossRef]

53. Genty, B.; Meyer, S. Quantitative mapping of leaf photosynthesis using chlorophyll fluorescence imaging. Aust. J. Plant Physiol. 1994, 22, 277-284. [CrossRef]

54. Mott, K.A. Effects of patchy stomatal closure on gas exchange measurements following abscisic acid treatment. Plant Cell Environ. 1995, 18, 1291-1300. [CrossRef]

55. Omasa, K.; Takayama, K. Simultaneous measurement of stomatal conductance, non-photochemical quenching, and photochemical yield of photosystem II in intact leaves by thermal and chlorophyll fluorescence imaging. Plant Cell Physiol. 2003, 44, 1290-1300. [CrossRef] [PubMed]

56. Calatayud, A.; Roca, D.; Martínez, P.F. Spatial-temporal variations in rose leaves under water stress conditions studied by chlorophyll fluorescence imaging. Plant Physiol. Biochem. 2006, 44, 564-573. [CrossRef] [PubMed]

57. Moustakas, M.; Malea, P.; Zafeirakoglou, A.; Sperdouli, I. Photochemical changes and oxidative damage in the aquatic macrophyte Cymodocea nodosa exposed to paraquat-induced oxidative stress. Pest. Biochem. Physiol. 2016, 126, 28-34. [CrossRef] [PubMed] 
58. Apel, K.; Hirt, H. Reactive oxygen species: Metabolism, oxidative stress, and signal transduction. Annu. Rev. Plant Biol. 2004, 55, 373-399. [CrossRef] [PubMed]

59. Gawroński, P.; Witoń, D.; Vashutina, K.; Bederska, M.; Betliński, B.; Rusaczonek, A.; Karpiński, S. Mitogen-activated protein kinase 4 is a salicylic acid-independent regulator of growth but not of photosynthesis in Arabidopsis. Mol. Plant 2014, 7, 1151-1166. [CrossRef] [PubMed]

60. Wang, W.H.; He, E.M.; Chen, J.; Guo, Y.; Chen, J.; Liu, X.; Zheng, H.L. The reduced state of the plastoquinone pool is required for chloroplast-mediated stomatal closure in response to calcium stimulation. Plant J. 2016, 86, 132-144. [CrossRef] [PubMed]

61. Küpper, H.; Mijovilovich, A.; Meyer-klaucke, W.; Kroneck, P.M.H. Tissue- and age-dependent differences in the complexation of cadmium and zinc in the cadmium/zinc hyperaccumulator Thlaspi caerulescens (Ganges Ecotype) revealed by X-ray absorption spectroscopy. Plant Physiol. 2004, 134, 748-757.

62. Ma, J.F.; Ueno, D.; Zhao, F.J.; McGrath, S.P. Subcellular localization of Cd and Zn in the leaves of a Cd-hyperaccumulating ecotype of Thlaspi caerulescens. Planta 2005, 220, 731-736. [CrossRef] [PubMed]

63. Ebbs, S.D.; Zambrano, M.C.; Spiller, S.M.; Newville, M. Cadmium sorption, influx, and efflux at the mesophyll layer of leaves from ecotypes of the Zn/Cd hyperaccumulator Thlaspi caerulescens. New Phytol. 2009, 181, 626-636. [CrossRef] [PubMed]

64. Demmig-Adams, B.; Adams, W.W.A., III. Photoprotection in an ecological context: The remarkable complexity of thermal energy dissipation. New Phytol. 2006, 172, 11-21. [CrossRef] [PubMed]

65. Moustaka, J.; Moustakas, M. Photoprotective mechanism of the non-target organism Arabidopsis thaliana to paraquat exposure. Pest. Biochem. Physiol. 2014, 111, 1-6. [CrossRef] [PubMed]

66. Agathokleous, E. Environmental hormesis, a fundamental non-monotonic biological phenomenon with implications in ecotoxicology and environmental safety. Ecotoxicol. Environ. Saf. 2018, 148, 1042-1053. [CrossRef]

67. Georgieva, K.; Doncheva, S.; Mihailova, G.; Petkova, S. Response of sun- and shade-adapted plants of Haberlea rhodopensis to desiccation. Plant Growth Regul. 2012, 67, 121-132. [CrossRef]

68. Jusovic, M.; Velitchkova, M.Y.; Misheva, S.P.; Börner, A.; Apostolova, E.L.; Dobrikova, A.G. Photosynthetic responses of a wheat mutant (Rht-B1c) with altered DELLA proteins to salt stress. J. Plant Growth Regul. 2018, 37, 645-656. [CrossRef]

69. Moustaka, J.; Ouzounidou, G.; Sperdouli, I.; Moustakas, M. Photosystem II is more sensitive than photosystem I to $\mathrm{Al}^{3+}$ induced phytotoxicity. Materials 2018, 11, 1772. [CrossRef] [PubMed]

70. Moustaka, J.; Ouzounidou, G.; Bayçu, G.; Moustakas, M. Aluminum resistance in wheat involves maintenance of leaf $\mathrm{Ca}^{2+}$ and $\mathrm{Mg}^{2+}$ content, decreased lipid peroxidation and $\mathrm{Al}$ accumulation, and low photosystem II excitation pressure. BioMetals 2016, 29, 611-623. [CrossRef] [PubMed]

71. Callahan, D.L.; Hare, D.J.; Bishop, D.P.; Doble, P.A.; Roessner, U. Elemental imaging of leaves from the metal hyperaccumulating plant Noccaea caerulescens shows different spatial distribution of Ni, Zn and Cd. RSC Adv. 2016, 6, 2337-2344. [CrossRef]

72. Chen, X.; Ouyang, Y.; Fan, Y.; Qiu, B.; Zhang, G.; Zeng, F. The pathway of transmembrane cadmium influx via calcium-permeable channels and its spatial characteristics along rice root. J. Exp. Bot. 2018, 69, 5279-5291. [CrossRef] [PubMed]

73. Antonoglou, O.; Moustaka, J.; Adamakis, I.D.; Sperdouli, I.; Pantazaki, A.; Moustakas, M.; Dendrinou-Samara, C. Nanobrass CuZn nanoparticles as foliar spray non phytotoxic fungicides. ACS Appl. Mater. Interfaces 2018, 10, 4450-4461. [CrossRef] [PubMed]

74. Hanć, A.; Małecka, A.; Kutrowska, A.; Bagniewska-Zadworna, A.; Tomaszewska, B.; Barałkiewicz, D. Direct analysis of elemental biodistribution in pea seedlings by LA-ICP-MS, EDX and confocal microscopy: Imaging and quantification. Microchem. J. 2016, 128, 305-311. [CrossRef]

75. Barceló, J.; Poschenrieder, C. Fast root growth responses, root exudates, and internal detoxification as clues to the mechanisms of aluminium toxicity and resistance: A review. Environ. Exp. Bot. 2002, 48, 75-92. [CrossRef]

76. Sperdouli, I.; Moustakas, M. Spatio-temporal heterogeneity in Arabidopsis thaliana leaves under drought stress. Plant Biol. 2012, 14, 118-128. [CrossRef] [PubMed]

77. Sperdouli, I.; Moustakas, M. Leaf developmental stage modulates metabolite accumulation and photosynthesis contributing to acclimation of Arabidopsis thaliana to water deficit. J. Plant Res. 2014, 127, 481-489. [CrossRef] [PubMed] 
78. Moustakas, M.; Malea, P.; Haritonidou, K.; Sperdouli, I. Copper bioaccumulation, photosystem II functioning and oxidative stress in the seagrass Cymodocea nodosa exposed to copper oxide nanoparticles. Environ. Sci. Pollut. Res. 2017, 24, 16007-16018. [CrossRef] [PubMed]

79. Lichtenthaler, H.K. The stress concept in plants: An introduction. Ann. N.Y. Acad. Sci. 1998, 851, 187-198. [CrossRef] [PubMed]

80. Wilson, K.E.; Ivanov, A.G.; Öquist, G.; Grodzinski, B.; Sarhan, F.; Huner, N.P.A. Energy balance, organellar redox status, and acclimation to environmental stress. Can. J. Bot. 2006, 84, 1355-1370. [CrossRef]

81. Guidi, L.; Calatayud, A. Non-invasive tools to estimate stress-induced changes in photosynthetic performance in plants inhabiting Mediterranean areas. Environ. Exp. Bot. 2014, 103, 42-52. [CrossRef]

82. Gorbe, E.; Calatayud, A. Applications of chlorophyll fluorescence imaging technique in horticultural research: A review. Sci. Hortic. 2012, 138, 24-35. [CrossRef]

83. Moustaka, J.; Tanou, G.; Adamakis, I.D.; Eleftheriou, E.P.; Moustakas, M. Leaf age dependent photoprotective and antioxidative mechanisms to paraquat-induced oxidative stress in Arabidopsis thaliana. Int. J. Mol. Sci. 2015, 16, 13989-14006. [CrossRef] [PubMed]

(C) 2018 by the authors. Licensee MDPI, Basel, Switzerland. This article is an open access article distributed under the terms and conditions of the Creative Commons Attribution (CC BY) license (http:/ / creativecommons.org/licenses/by/4.0/). 